Int. J. Dev. Biol. 58: 219-229 (2014)

doi: $10.1387 / \mathrm{ijdb} .140109 \mathrm{ss}$

\title{
Natural killer cells and regulatory T cells in early pregnancy loss
}

\author{
SURENDRA SHARMA* \\ Women and Infants Hospital of Rhode Island, Warren Alpert Medical School of Brown University, \\ Department of Pediatrics, Providence, Rhode Island, USA
}

\begin{abstract}
Survival of the allogeneic embryo in the uterus depends on the maintenance of immune tolerance at the maternal-fetal interface. The pregnant uterus is replete with activated maternal immune cells. How this immune tolerance is acquired and maintained has been a topic of intense investigation. The key immune cells that predominantly populate the pregnant uterus are natural killer (NK) cells. In normal pregnancy, these cells are not killers, but rather provide a microenvironment that is pregnancy compatible and supports healthy placentation. In placental mammals, an array of highly orchestrated immune elements to support successful pregnancy outcome has been incorporated.This includes active cooperation between maternal immune cells, particularly NK cells, and trophoblast cells. This intricate process is required for placentation, immune regulation and to remodel the blood supply to the fetus. During the past decade, various types of maternal immune cells have been thought to be involved in cross-talk with trophoblasts and in programming immune tolerance. RegulatoryT cells (Tregs) have attracted a great deal of attention in promoting implantation and immune tolerance beyond implantation. However, what has not been fully addressed is how this immune-trophoblast axis breaks down during adverse pregnancy outcomes, particularly early pregnancy loss, and in response to unscheduled inflammation. Intense research efforts have begun to shed light on the roles of NK cells and Tregs in early pregnancy loss, although much remains to be unraveled in order to fully characterize the mechanisms underlying their detrimental activity. An increased understanding of host-environment interactions that lead to the cytotoxic phenotype of these otherwise pregnancy compatible maternal immune cells is important for prediction, prevention and treatment of pregnancy maladies, particularly recurrent pregnancy loss. In this review, we discuss relevant information from experimental and human models that may explain the pregnancy disrupting roles of these pivotal sentinel cells at the maternal-fetal interface.
\end{abstract}

KEY WORDS: pregnancy, immune tolerance, inflammation/infection, NK cell, Treg

\section{Introduction}

Pregnancy is a unique and well-choreographed physiological process that involves dynamic maternal and fetal dialogue. Local immune tolerance, angiogenesis, cytokine and hormonal balance, cellular and molecular mimicry, genetic and epigenetic as well as environmental cues influence pregnancy outcomes (Dosiou and Giudice 2005; Thaxton and Sharma 2010; Zhang et al., 2011; Hemberger 2012; Van Dijk and Oudejans 2013; Hughes 2014; Rai and Cross 2014). Moreover, starting from implantation through gestation and parturition, the interplay of inflammatory and antiinflammatory signaling, hormonal changes, and cellular events are central to normal pregnancy outcomes (Murphy and Sharma 2004).
Keeping these events in mind, successful reproduction relies on limited inflammation during implantation, immune tolerance (antiinflammation) during the mid-pregnancy, and inflammation again during parturition. Adverse pregnancy outcomes are a consequence of impairment of more than one of these factors that result in adaptation failure. In this regard, we and others have previously proposed that adverse pregnancy outcomes may be a consequence of at least a two hit mechanism whereby a genetic predisposition may

Abbreviations used in this paper: $\mathrm{dNK}$, decidual NK cell; hCG, human chorionic gonadotropin; LPS, lipopolysaccharide; NK cell, natural killer cell; NKG2D, natural killer group 2 member D; poly I:C, polyinosinic:polycytidylic acid; RSA, recurrent spontaneous abortion; Treg, regulatory $\mathrm{T}$ cell.

\footnotetext{
*Address correspondence to: Surendra Sharma. Women and Infants Hospital, Department of Pediatrics, 101 Dudley Street, Providence, RI 02905, USA. Tel: +1-(401)-274-1122, ext. 48004. Fax: +1-(401)-277-3617. E-mail: ssharma@wihri.org
} 
be complemented by an environmental insult to cause pregnancy disruption (Murphy et al., 2005; Mor and Cardenas 2010).

Parents and obstetricians have become increasingly interested in understanding pregnancy complications such as repeated implantation failures, recurrent spontaneous miscarriage, preterm birth, intrauterine growth restriction (IUGR), preeclampsia, and gestational diabetes. These pregnancy complications have been on a rise globally despite better clinical management. All of these adverse pregnancy outcomes inure huge financial and emotional burdens on the caregivers and parents. Several of these complications are the leading cause of maternal and neonatal mortality and morbidity. Surprisingly, these devastating pregnancy maladies have remained enigmatic. Recent efforts to understand the etiologies underlying adverse pregnancy outcomes have focused on immune tolerance, angiogenesis, and hormonal regulation at the maternalfetal interface (LeBouteiller and Tabiasco 2006; Quenby et al., 2009; Schumacher et al., 2013). The concept of immune tolerance in the context of pregnancy relates to the fact that a healthy woman can successfully carry a semi-allogeneic pregnancy to full term without rejection by the mother's fully functional immune system. Maternal tolerance and anti-inflammatory microenvironment are essential to prevent rejection of the semi-allogeneic fetus and are mediated, in part, by tightly regulated cross-talk between uterine immune cells and placental trophoblast cells (Croy et al., 2012; Erlebacher 2013a). In regards to angiogenesis during pregnancy, there are striking similarities between placental invading trophoblast cells and tumor cells. Similar to tumor formation, physiological mechanisms mediated by uterine immune cells, particularly natural killer (NK) cells and regulatory T cells (Tregs), promote angiogenesis by producing angiogenic factors, cytokines and chemokines (Hanna et al., 2006; Kalkunte et al., 2009; Lash et al., 2010; Saito et al., 2013). These operate to allow invasion of fetal-derived trophoblast cells and transformation of uterine spiral arteries that regulate maternal blood flow to the fetus. Hormonal regulation is critical for all phases of pregnancy, including implantation, maintenance of pregnancy and parturition. Several recent reviews have focused on aspects of maternal-fetal interactions in pregnancy (Quenby et al., 2009; Lash et al., 2010; Mor and Cardenas 2010; Thaxton and Sharma 2010; Erlebacher 2013a; Saito et al., 2013). It is now believed that unscheduled breakdown of this highly choreographed process by infections, inflammation, (epi)genetic changes, stress and dysregulated protein homeostasis can contribute to gestational age-dependent pathologies (Burton et al., 2009; Jabbour et al., 2009; Weiss et al., 2009; Robins et al., 2011). Moreover, the growing number and diversity of pregnancy complications with neonatal maladies demand a broad-based research strategy to understand and combat these devastating clinical issues.

Afundamental question in reproductive immunology, one that also raises practical considerations that impact local immune tolerance and successful pregnancy outcome, is whether uterine NK cells and Tregs change their pregnancy-friendly and immune tolerant phenotype to an adverse phenotype in the setting of excessive inflammation, infection and stress. Mild, beneficial inflammationlike responses are normally elicited during implantation, possibly induced by semen (seminal fluid) (Robertson et al. 1996, 2009; Troedsson et al., 2001). Pivotal roles of inflammatory cytokines such as GM-CSF, LIF, IL-1, IL-6, and IL-11 have been implicated in successful implantation and decidualization (Stewart et al., 1992; Singh et al., 2011). The role of inflammation in initiating implantation is further suggested by the effect of unexpected observations of endometrial injury due to biopsy procedure in patients undergoing in vitrofertilization (IVF) treatment (Barash et al., 2003; Gnainsky et al., 2010). These patients had a history of multiple failed implantation but experienced remarkable positive outcomes after biopsy-induced injury. This observation implies that local injury induced an inflammatory microenvironment which supported uterine receptivity for blastocyst attachment. A balancing anti-inflammatory immunity is then imposed despite an abundance of NK cells, macrophages and $\mathrm{T}$ cells at the maternal-fetal interface. Fetal trophoblast cells are equally important partners in exerting immune tolerance. Accumulating evidence in humans now suggests that at least NK cells and Tregs undergo proportional or functional changes in patients with recurrent spontaneous abortion (La Chapelle et al., 1996; Sasaki et al., 2004; Kwak-Kim et al., 2010; Quinn and Parast 2013). This raises two important questions: 1. Do uterine NK (uNK) cells and Tregs undergo similar changes and/or become inflammatory and 2. What mechanisms are elicited for their altered characteristics? Below, we first discuss the unique properties of uterine NK cells and Tregs and their non-destructive functions in normal pregnancy. We will further discuss experimental and clinical evidence for their destructive functions contributing to early pregnancy fetal loss.

\section{Uterine NK cells and Tregs in pregnancy: why are they there in abundance?}

Since the recognition of the immunological paradox associated with survival of the allogeneic embryo over 60 years ago by Sir Peter Medawar (Medawar 1953), the precise mechanisms whereby the conceptus evades the maternal immune system still remain obscure. Multiple maternal immune adaptations are potentially involved and have recently been reviewed elsewhere (Moffett and Loke 2006; Quenby et al., 2009; Thaxton and Sharma 2010; Munoz-Suano et al., 2011; Chakraborty et al., 2012; Hofmann et al., 2014). Here we focus on uterine NK (uNK) cells and Tregs because they are the predominant cell types present at the maternal-fetal interface which may pose as foes to pregnancy.

\section{Human uterine NK cells}

During the pre-ovulatory phase, only a few, small and agranular NK cells are present in the endometrium (Peel 1989; Kalkunte et al., 2008; Le Bouteiller and Piccinni 2008). There is dramatic increase in the number of these cells during the secretory phase of the menstrual cycle as progesterone levels increase. These numbers rise further if the pregnancy ensues. Since progesterone levels drop at the end of the menstrual cycle and NK cells also undergo death, it has been proposed that their survival depends on progesterone. NK cells become granulated and come in contact with vessels and endometrial glands (Peel 1989; Croy and Kiso 1993; Moffett and Loke 2006; Manaster and Mandelboim 2010). They constitute almost $70 \%$ of all mononuclear cells in the pregnant womb. Their number decreases from mid gestation and these cells are almost absent at term. Based on their name, NK cells are often considered to be deleterious (or cytotoxic), killing virally-infected cells and cancer cells (Biron 2010). However, this killing phenotype is lost in the pregnant uterus, instead NK cells play a supportive role. As stated above, NK cells are the dominant immune cell type in the uterine mucosa during active phase of placentation despite being armed with the complete killing machinery. They express the full reper- 
toire of the NK activating receptors which include NKp46, NKp30 and NKG2D (Hanna et al., 2003; Kusumi et al., 2006; Tabiasco et al., 2006; Kalkunte et al., 2009). Furthermore, all uNK cells have been shown to express the NKp44 receptor (Hanna et al., 2003; Kusumi et al., 2006; Kalkunte et al., 2009) whose expression can be normally detected only after NK cell activation (Arnon et al., 2006). Phenotypic characteristics confirm that UNK cells are indeed non-T cells, but are not like NK cells found in blood. The majority of UNK cells are CD56 ${ }^{\text {bright }}$ CD16-, while most NK cells in blood are CD56 ${ }^{\text {dim }}$ CD $16^{+}$. Although a small subset of CD56 bright NK cells (10\%) is detected in peripheral blood, these cells tend to be different from uNK cells (Nagler et al., 1989; King and Loke 1991). Since uterine NK cells increase dramatically at the time of placentation, it has been debated whether trophoblasts are needed to support their proliferation. It is noteworthy to mention here that uNK cells are present in decidualized pseudopregnant rats or mice. They are probably phenotypically distinct from uNK cells accumulating in a pregnant uterus (Peel et al., 1979; Stewart 1988; Zheng et al., 1991). Two observations suggest that trophoblasts may not be a prerequisite for uNK cell amplification. First, in ectopic pregnancies, decidualized endometrium contains NK cells in the absence of trophoblasts (Vassiliadou and Bulmer 1998). Second, IL-15 deficient female mice do exhibit implantation and placentation but lack the presence of uNK cells (Croy et al., 2003). These data also suggest that uNK cells may not influence implantation per se.

\section{Mouse uNK cells}

Similar to humans, the pregnant mouse also develops a hemochorial placenta to support embryo development and evades a destructive immune response despite high accumulation of pregnancy-specific uNK lymphocytes in the pregnant uterus (Chakraborty et al., 2011; Croy et al., 2012). As a matter of fact, because of hemochorial placentation, mouse models have been the major source of mechanistic understanding of the uNK cell biology (Paffaro et al., 2003; Yadi et al., 2008). In this regard, the genetic manipulation approaches involving target genes with silenced or up-regulated expression are the most helpful tools to study the temporal and developmental role of uNK cells in pregnancy. The dynamic, rapid changes at the maternal-fetal interface in a 3 week long mouse gestation compared to a 40 week human pregnancy, as well as anatomical differences between human and mouse reproductive organs, pose challenges for simple, direct translation of mechanistic information from the mouse models to humans. However, similarities in uNK cell immunobiology during pregnancy largely surpass the anatomical and physiological differences between mice and humans.

Phenotypic characterization of mouse uNK cells has been distinguished by a unique staining pattern with Dolichos biflorus (DBA) lectin. Mouse uNK cells can also be distinguished as cells containing amylase-resistant periodic acid Schiff (PAS) positive granules. Yamada and colleagues established the DBA staining approach a decade ago to identify and localize mouse uNK cells in the histological sections of the pregnant uterus from gestational day (gd) 6 to term in the same apparent pattern for all wild type mouse strains (Paffaro et al., 2003). Using DBA staining as an approach in flow cytometric analysis, Yadi and colleagues (Yadi et al., 2008) determined that DBA lectin identifies $95 \%$ of uNK cells. DBA lectin recognizes a glycoconjugate containing $\mathrm{N}$-acetyl $\mathrm{D}$-galactosamine terminal sugar moiety present in the plasma membrane and gran- ules of uNK cells. Therefore, both granule-rich and agranular UNK cells can be successfully identified (Paffaro et al., 2003; Yadi et al., 2008), whereas PAS or perforin stain scores only granule-rich mature uNK cells. Indeed, only $45 \%$ of DBA ${ }^{+}$UNK cells are perforin positive on gd 8 and 12 (Yadi et al., 2008). Importantly, peripheral blood NK cells, non-pregnant endometrial NK (CD11c NK1.1+DX5+ eNK) cells, and other leukocytes are not reactive to DBA (Paffaro et al., 2003; Yadi et al., 2008). Recent observations suggest that DBA staining can identify subtypes of uNK cells with varying proportion of granulation which appear in the pregnant uterus in a gestational age-dependent manner. Cytolytic perforin is a common marker of both peripheral blood NK cells and uNK cells.

Mouse uNK cells can also be identified based on the CD3 CD122+ phenotype (Paffaro et al., 2003; Yadi et al., 2008) and further distinguished into minor DBA-NKp46+NK1.1+DX5+NKG2D+ and major DBA+NKp46+NK1.1-DX5-NKG2D+ subsets characterized from uterine mononuclear cells harvested on gestational day (gd) gd 10 from C57BL/6 mice. The minor subpopulation resembles that characterized as endometrial NK (eNK) cells as discussed above. The major subpopulation is unique because it is $\mathrm{DBA}^{+}$but lacks expression of NK1.1 and DX5, usual markers of mature peripheral blood NK cells. Therefore, DBA lectin is the simplest method to identify most mouse uNK cells found in the pregnant uterus.

\section{Uterine regulatory $T$ cells}

In 1990s, a previously rejected immune concept reemerged that revolutionized the research on immune tolerance. This research dealt with the regulatory $T$ cells (Tregs) rediscovered by Sakaguchi and colleagues (Sakaguchi et al., 1995). These researchers revived the old concept of suppressor cells, championed by Richard Gershon 30 years ago (Gershon and Kondo, 1970). These cells are now identified as CD4+CD25+ Tregs. Interestingly, Tregs are thought to be essential in the generation of maternal-fetal tolerance in mice and humans (Erlebacher 2013a; Robertson et al., 2013; Schumacher and Zenclussen 2014). This is in agreement with their well-known role in self-tolerance and in maintaining balanced immune responses (Tilburgs et al., 2008; Erlebacher 2013b). Their clinical importance lies in the observations that reduced numbers and function of Tregs is associated with the incidence of autoimmunity (Sakaguchi et al., 2008). Their elevated numbers are detected in cancer tissues (Zou, 2006). On the other hand, increasing their number has had therapeutic implications in experimental models of autoimmunity and graft-versus-host disease. Although the CD4 ${ }^{+} \mathrm{CD} 25^{+}$phenotype may also be associated with activated CD4 T cells, Tregs express their signature transcription factor, forkhead box protein 3 (FoxP3), which activates genes required for suppressor functions and maintains the effector transcriptional program of the Treg lineage cells (Schubert et al., 2001; Veiga-Parga et al., 2013). These cells produce immunosuppressive cytokines IL-10 and TGF- $\beta$, an effector characteristic for exerting immune tolerance at the maternal-fetal interface (Hara et al., 2001; Friedline et al., 2009; Rabinovich and Toscana, 2009).

Early pregnancy decidua contains an abundance of CD4+CD25 ${ }^{\text {bright } F o x P 3+~} T$ cells in both humans and mice (Tilburgs et al., 2008; Xiong et al., 2010; Liu et al., 2013; Saito et al., 2013; Schumacher and Zenclussen, 2014). The pioneering work by Robertson and colleagues suggests that exposure of the uterus to male seminal fluid which contains cytokines and chemokines prepares the local microenvironment to expand and to attract 
Tregs that react with paternal alloantigens (Robertson et al., 2013). Female dendritic cells recognize fetal antigens and cross-present seminal fluid antigens which induce transformation of effector CD4 T cells into induced Tregs (Erlebacher 2013b). These newly induced Treg cells are eventually recruited to the endometrium. Several groups have demonstrated that Tregs are essential for productive implantation as lack of these cells has been associated with implantation failure (Sasaki et al., 2004; Quinn and Parast, 2013; Saito et al., 2013; Teles et al., 2013; Schumacher and Zenclussen, 2014). In mice and humans, although these cells reach their peak through mid gestation, it is not clear whether Tregs play any role in maintaining pregnancy as their depletion after gd 6 of mouse pregnancy does not appear to affect the maintenance of pregnancy to term (Fig. 1). On the other hand, transfer of induced Tregs to an abortion-prone mating combination or to mating combinations where pregnancy has been challenged by inflammation or stress protects pregnancy to term, implying that they may play role beyond implantation (Aluvihare et al., 2004; Wang et al., 2014). It has been suggested that Tregs at the maternal-fetal interface are mainly of extrathymic origin (induced peripheral blood Tregs). However, recruitment of thymus-derived Tregs could not be ruled out as there is only minimum effect of genetic depletion of extrathymic Tregs on pregnancy outcome as characterized in mice lacking the conserved non-coding sequence 1 (CNS1) enhancer element in the first intron of the FoxP3 gene (Samstein et al., 2012). These mice lack propagation of extrathymic (induced) Tregs. Furthermore, it has been proposed that thymus-derived

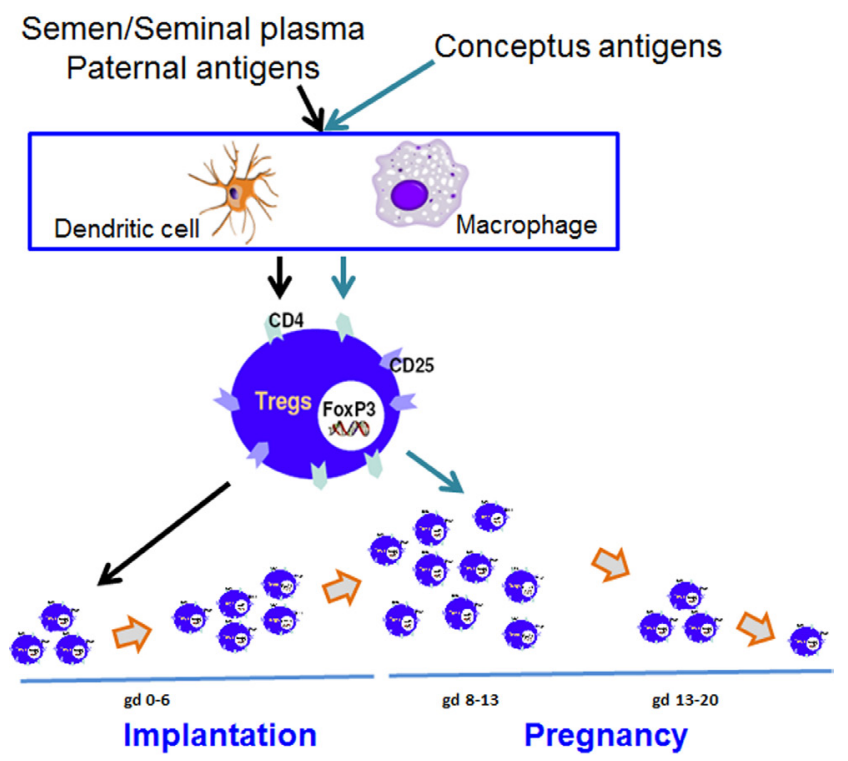

Fig. 1. Generation of semen/seminal fluid and conceptus-specific uterine regulatory $\mathbf{T}$ cells (Tregs) in the mouse. During the pre-implantation phase, Tregs can be generated in response to semen/seminal plasma paternal antigens. These cells have been shown to play an important role in implantation. However, Tregs reach their peak around gestational day 12 or 13. We propose that conceptus-specific Tregs contribute to influx of $\mathrm{CD}^{+} \mathrm{CD}_{25} \mathrm{FoxP}^{+}$Tregs after implantation. These Tregs could be of extrathymic origin and support maintenance of immune tolerance and promote angiogenesis. These cells start tapering off after gestational day 13 and reach basal numbers at the end of pregnancy. It is possible that Tregs could also be modified or poorly propagated in response to hormone dyregulation and/or inflammatory environment.
Helios $^{+}$Tregs accumulate in the lymph node draining the uterus during early pregnancy. Induced Tregs could be expanded and accumulated in the periphery during later stages of pregnancy (Schumacher and Zenclussen, 2014). Nevertheless, a common notion is that Tregs can protect against fetal loss in abortion-prone mice or in response to inflammatory triggers in pregnant mice, suggesting that induced Tregs can protect against systemic and uterine inflammatory immune responses.

Uterine Tregs mediate potent inhibition of activated autologous CD4 ${ }^{+}$CD25-T cell proliferation. This suppressive function of decidual Tregs requires cell-to-cell contact. Although there is a suggestion that decidual Tregs contribute to the mechanism of immune tolerance to fetal antigens, the nature of such antigens is still poorly understood (Erlebacher 2013b). The studies on decidual Tregs raise several questions concerning the temporal importance beyond implantation and their response under destructive conditions. One major unresolved issue is the exact role of Tregs in pregnancy, particularly in the context of their stated role in suppression of conceptus-specific conventional $\mathrm{CD} 4^{+} \mathrm{T}$ cells that would otherwise attack fetal tissue. This idea is based solely on the observations that depletion of Tregs significantly contributes to fetal rejection only in allogeneic mating combinations but not in syngeneic mating combinations (Aluvihare et al., 2004). However, these experiments do not address the issue of other pathways that may derail immune tolerance in both allogeneic and syngeneic mating combinations. It is assumed that similar pathways are operational in both humans and mice as uterine Tregs follow a similar pattern for their gestational age-dependent frequency, antigen specificity, factors that influence their propagation, recruitment, and with their dramatic reduction after mid-gestation. Surprisingly, circulating Tregs also follow a similar pattern of pregnancy-dependent increase and decrease. The proportional fluctuation in peripheral blood Tregs during pregnancy parallels hormonal increase or decrease, particularly that of human chorionic gonadotropin (hCG) and progesterone (Norris et al., 2011; Schumacher et al., 2013). Indeed, our recent observations and those of others suggest that mouse uterine Tregs are responsive to hCG which may promote their recruitment to the pregnant uterus (Norris et al., 2011). Tregs significantly decline at term, probably in response to the onset of labor. This agrees with the recent observations of changes in Treg functions in preterm labor deliveries (Seol et al., 2008; Xiong et al., 2010; Schober et al., 2012).

\section{Why are uterine NK cells and Tregs present in abundance during pregnancy?}

\section{Implantation}

Is there any other role that abundant UNK cells or Tregs play in addition to maintaining immune tolerance? Since these immune cells are present at the time of implantation or appear immediately after that, it is possible that they play a key role during the implantation window. As discussed above in the context of mouse models of pregnancy, Tregs are recruited during the pre-implantation period and their depletion prior to implantation (gd 5 in mouse) leads to failed embryo implantation, suggesting that they are an active regulator of implantation. However, uNK cells may not be part of the implantation machinery for the following reasons: 1. NK cell deficient mice show normal implantation and pregnancy outcome (Croy et al., 2010); 2. Although non pregnant eNK cells 
are differentiated into decidual NK cells and their numbers increase dramatically in response to pregnancy, it is not clear yet whether fetal tissue is responsible for their pregnancy-related differentiation (Manaster and Mandelboim 2010); and 3. In humans, ectopic pregnancies are associated with high numbers of NK cells in the absence of embryo implantation and trophoblast invasion (Vassiliadou and Bulmer 1998). These observations suggest that UNK cells are required for post-implantation functions. Since NK cells expand in decidualized pseudopregnant uteri in the absence of any trophoblasts (Peel et al., 1979; Stewart 1988; Zheng et al., 1991), this also supports the concept that trophoblasts are not required for their accumulation in the uterus.

Antigenic cross-talk between uterine immune cells and fetal tissue

The fetal tissue (placenta) is an immunologically dynamic organ capable of presenting foreign antigens, capable of producing an array of immune modulating factors, capable of expressing Toll-like receptors (TLRs) that can recognize endogenous and exogenous signals to activate the maternal immune system, and capable of secreting a wide spectrum of proteases which maintain an active protein degradation machinery (Riley and Yokoyama 2008). This suggests that in most part, interactions between the maternal immune cells and trophoblasts cells are not devoid of antigenic crosstalk. In mice, recent experiments suggest that most trophoblasts express the classical, polymorphic $\mathrm{MHC}$ class I molecule $\mathrm{H} 2-\mathrm{K}$ from both the maternal and paternal alleles (Drake and Head 1989). This may indicate a requirement for limited $\mathrm{H} 2-\mathrm{K}$-mediated immune responses that are necessary for reorganization of the placental architecture, but not tissue destruction. This does not preclude the possibility that trophoblast cells are resistant to immune attack in all scenarios. The pathways that lead to ectopic pregnancy may lead to trophoblast destruction irrespective of $\mathrm{H} 2-\mathrm{K}$ expression (Drake and Head 1989; Erlebacher et al., 2002). This has been demonstrated by the observations that allogeneic mouse trophoblast stem cells placed at ectopic sites of host mice are rejected. It is possible that NK cells and Tregs at ectopic sites are destructive in nature. Both uNK cells and uterine Tregs have been shown to be potent sources of anti-inflammatory molecules, including the cytokine IL-10. These cells appear to be specialized compared to their circulating counterparts. UNK cells that harbor full cytotoxic machinery, however, fail to kill trophoblast cells. Rather, their noncytotoxic cross-talk with trophoblasts has been demonstrated in both humans and mice (Kopcow et al., 2005). It has been suggested that uNK cells fail to form an active immunological synapse with target cells. However, if uNK cells are cultured in vitro with or without stimuli such as IL-2, they are likely to revert back to their killing phenotype (Co et al., 2013). This suggests that the decidual microenvironment supports their immune tolerance (constructive) phenotype. Thus, the dramatic presence of uNK cells is probably required for both immune as well as non-immune functions as discussed below, and it is most probably accomplished by their ability to produce regulatory cytokines, chemokines, and growth factors.

It is well documented now that both peripheral blood and uterine Tregs increase in response to productive implantation (Sasaki et al., 2004; Schumacher and Zenclussen, 2014). Accumulating evidence suggests that the recognition of foreign paternal/fetal antigens by Tregs is critical for their development and functions (Erlebacher 2013b). These results raise an important question concerning the location, timing and mechanisms for alloantigen- specific Tregs during pregnancy. Several groups have now demonstrated that both seminal fluid and sperm can foster induction of the Treg phenotype in naïve CD4 ${ }^{+} \mathrm{T}$ cells, as originally shown by Robertson and colleagues (Guerin et al., 2011; Balandya et al., 2012; Liu et al., 2013). The first wave of increase in Tregs may occur as a result of exposure of antigen presenting cells in the vaginal lumen when they come in contact with paternal antigens in seminal fluid. These antigens are presented to $T$ cells in the regional lymph nodes. This will then increase Tregs in these lymph nodes in response to semen. Importantly, semen/seminal fluid contain high levels of TGF- $\beta$ which is likely to expand the Treg population (Robertson et al., 2013). However, this still does not explain the dichotomy of semen versus conceptus-specific antigen induced Treg cell development (Erlebacher 2013b). We propose that normal gestation may be associated with both semen and conceptus-induced Tregs. Semen/seminal fluid-induced Tregs develop early and may be present during the pre-implantation and implantation window, whereas conceptus-specific Tregs may appear later during pregnancy (Fig. 1). Interestingly, peripheral blood and uterine Tregs reach their peak at mid gestation. It is thus possible that they represent two populations and could be of the thymic and extrathymic origins. These Tregs are clearly there to provide immune tolerance against alloantigen-specific effector $\mathrm{CD}^{+} \mathrm{T}$ cells which are also generated in response to fetal antigens. They may also be involved in enhancing the anti-inflammatory milieu by producing IL-10 and TGF- $\beta$.

\section{Spiral artery remodeling and angiogenesis}

The most important contribution of uNK cells has been their participation in transformation of endometrial vessels, coiled spiral artery structures, into wide low-resistance canals that in turn allow transfer of blood, nutrients, and oxygen from the mother to the placenta and fetus. A critical adaptation in this process is the extensive vascular remodeling at the maternal-fetal interface which involves uNK cells and possibly Tregs and invasive or extravillous trophoblast cells. The landmark studies by Croy and colleagues first demonstrated the novel concept of tissue remodeling functions of uNK cells (Croy et al., 2003). Their work suggested that NK deficient pregnant mice displayed thickening of the walls of spiral arteries. Restoration of uNK cells could correct this defect. Administration of exogenous IFN- $\gamma$ to alymphoid pregnant mice also supports productive spiral artery remodeling (Ashkar and Croy 1999), suggesting that uNK cells or any other endometrial cells exert their tissue remodeling activity mainly through production of this cytokine. However, the concept of IFN- $\gamma$-mediated spiral artery transformation is not yet confirmed in humans. Is trophoblast invasion regulated by uNK cells or their product IFN- $\gamma$ ? Importantly, Soares and colleagues have demonstrated that NK cell depletion in the rat leads to hypoxia and initial delays in spiral artery remodeling; however, invasive trophoblast cells are activated and able to successfully modify the uterine spiral arteries. The authors further demonstrate that increased trophoblast invasion/uterine spiral artery remodeling is an adaptive response regulated by NK cells, and this process might be somewhat delayed in the absence of NK cells but resumes in a delayed manner (Chakraborty et al., 2011, 2012). However, these results do not rule out an independent role of cytokines such as IFN- $\gamma$ in spiral artery remodeling.

In humans, uNK cells have been assigned the novel function of encouraging angiogenic activity involving invading trophoblasts 
and spiral artery endothelial cdlls. Human uNK cells are potent secretors of a variety of angiogenic factors in early pregnancy, including VEGF-C, IL-8, IP-10, placental growth factor (PLGF), and angiopoietins (Hanna et al., 2006; Kalkunte et al., 2009; Vacca et al., 2013). These characteristics differ from their peripheral blood NK cells. Hanna et al., demonstrated that decidual NK cells differ from peripheral blood and non-pregnant endometrial NK cells and promote vascular growth which depends on uNK cell receptor-ligand interactions (Hanna et al., 2006). Kalkunte et al., have demonstrated that NK cell-derived angiogenic factors are responsible for maintaining their non-cytotoxic phenotype (Kalkunte et al., 2009). These observations raise an important question of the exact conditions that transform peripheral blood and endometrial NK cells. Recent observations by Cerdeira et al., provide important clues to this important question (Cerdeira et al., 2013). They propose that exposure of human peripheral blood NK cells to a combination of hypoxia, TGF- $\beta 1$, and a demethylating agent converts these cells into decidual NK cell-like cells. This is associated with induction of the expression of Ig-like receptors, CD9 and CD49a, chemokine receptors, and production of vascular endothelial growth factor. These approaches are likely to enhance our understanding of specialized NK cells and their associated vascular activity. These studies also place killer lg-like receptors (KIR) in a central role. In this process, the nature of cross-talk between uNK cells and trophoblasts through certain killer immunoglobulin receptors (KIR) on maternal NK cells and HLA-C alleles on invading trophoblast cells may influence the risk of preeclampsia, intrauterine growth

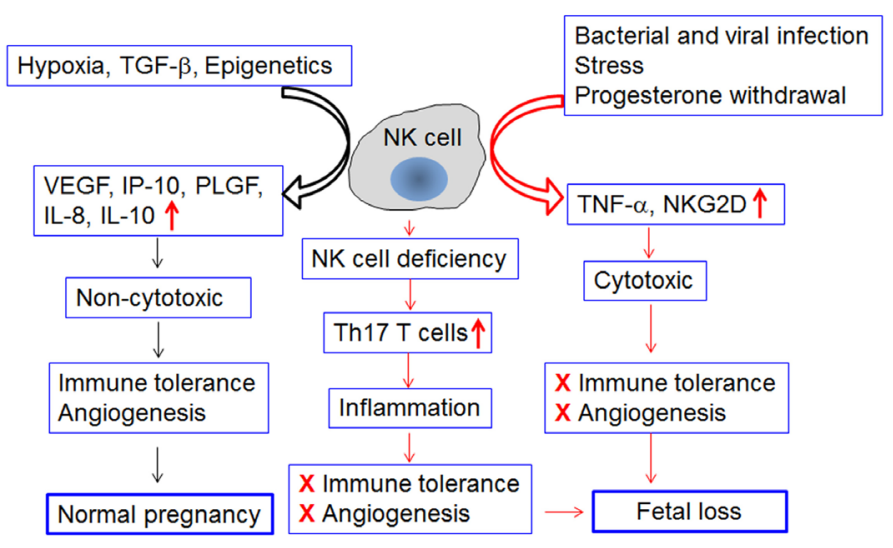

Fig. 2. Can uterine NK (uNK) cells become detrimental to normal pregnancy? In humans, non-cytotoxic uNK cells are phenotypically characterized as CD56 $6^{\text {bright }} C D 16$ and express full spectrum of natural cytotoxicity receptors (NCRs) and cytotoxic machinery. Their mouse counterparts are typically shown as DBA+ and may lose expression of NK1.1 and DX5 markers. Recent observations suggest that in both cases, UNK cells are potent producers of angiogenic factors and anti-inflammatory molecules. These properties make them helpers, rather than killers, of pregnancy. This pregnancy compatible role of uNK cells has been shown to be compromised in the scenarios of NK cell deficiency and exposure to inflammatory triggers. NK cell deficiency has been shown to encourage heavy recruitment of Th17 $T$ cells which cause pathogenic inflammation. Exposure to inflammatory triggers such as bacterial and viral mimics (LPS or poly l:C) may either convert UNK cells into TNF- $\alpha$-producing cells or encourage recruitment of NK cells which become TNF- $\alpha$ producing and NKG2Dbright $u N K$ cells. In an environment of poor immune tolerance and impaired angiogenesis, these NK cells are likely to induce fetal loss. restriction, and recurrent miscarriage (Hiby et al., 2004, 2010).

Emerging evidence from the studies on a link between angiogenesis and immune tolerance in tumor growth clearly points to potent and overlapping mechanisms. Hypoxia drives angiogenesis in tumors and also results in the release of inflammatory triggers that can lead to rejection of tumors. Thus, it has been suggested that the counter-activation mechanisms are invoked at the hypoxia site to maintain the immunological escape of tumors. It has been shown that tumor hypoxia promotes recruitment of Tregs which in turn promote immune tolerance and angiogenesis (Facciabene et al., 2011; Deng et al., 2013). A corollary of this is seen at the maternal-fetal interface. Uterine Tregs develop in response to fetal antigens and cross-talk with invading trophoblast cells (Erlebacher 2013b). They produce immunosuppressive and angiogenic factors, including IL-10 and TGF- $\beta$. This may be an important role for Tregs following the blastocyst implantation.

\section{Can uNK cells and Tregs become foes to pregnancy?}

As discussed earlier, uNK cells and Tregs are abundant during the early stages of pregnancy. The current evidence suggests that the primary role of uNK cells and Tregs is to exert immune tolerance and to promote the spiral arteriolar remodeling and trophoblast invasion, two key steps in placental growth and normal pregnancy (Pijnenborg et al., 1981; Blois et al., 2011; Chakraborty et al., 2012; Saito et al., 2013). A key question that has escaped necessary scrutiny is what happens to these cells when women experience recurrent spontaneous abortion or multiple implantation failures. Emerging evidence in humans, although controversial, suggests that circulating NK cells and Tregs undergo numerical or functional changes in patients with a history of spontaneous abortion, implantation failure or other pregnancy complications (Moffett et al., 2004). However, it is not clear whether these changes are reflected at the maternal-fetal interface (Moffett et al., 2004). Below, we review the experimental and clinical observations that support our initial view that uNK cells and possibly uterine Tregs turn into foes of pregnancy in response to inflammatory triggers.

\section{Experimental evidence}

\section{Uterine NK cells}

We showed that pregnant mice experienced fetal resorption when administered the bacterial product lipopolysaccharide (LPS) or a viral mimic poly IC (Murphy et al., 2005; Thaxton et al., 2013). Characterization of uterine immune cells suggested that uNK cells increased in response to LPS or poly IC but employed different mechanisms to induce fetal loss. The LPS treatmentmediated induction of UNK cells was associated with changes in their phenotypic and functional characteristics (Murphy et al., 2005). The LPS-induced increase in UNK cells was associated with an increase in NK1.1+ cells which became the potent source of excessive TNF- $\alpha$ at the maternal-fetal interface. These cells infiltrated into the placental zone, a feature not associated with normal pregnancy. Most uNK cells in mice on gd8-14 are NK1.1and DX5 ${ }^{-}$but are DBA ${ }^{+}$. This suggests that LPS treatment changed their phenotypic characteristics. Moreover, since depletion of NK cells supported pregnancy to term even in the presence of LPS, we conclude that uNK cells have the capability to turn into foes to pregnancy. Similarly, poly I:C treatment on gd6 resulted in exces- 
sive expression of NKG2D on uNK cells and the NKG2D ligand, Rae 1, on uterine macrophages (Thaxton et al., 2013). This led to excessive TNF- $\alpha$ production and fetal loss on gd 9 or 10 . The role of NKG2D+ NK cells in fetal loss was confirmed by depletion of NKG2D+ NK cells which resulted in protection of pregnancy to term. Surprisingly, in both cases, no changes were observed in the spleens of either treatment group.

Recently, it has been shown that uNK cells control Th17 T cells and maintain tolerance during allogeneic pregnancy. Using CBA/J $x \mathrm{DBA} / 2$ abortogenic mating, Fu et al., demonstrated that the percentage of Th17 T cells increased among the total decidual CD4+ T cell population when compared with syngeneic CBA/J mating or wild type allogeneic mating (Fu et al., 2013). These observations suggest that abortion-prone CBA/J $\times$ DBA/2 mating may be associated with detrimental presence of Th17 T cells. Importantly, it was further demonstrated that the absence of uNK cells promoted development of Th17 T cells at the maternal-fetal interface and that uNK cells exert their immune tolerance effects through suppression of Th17 T cells. Taken together, we propose that uNK cells have the ability to harm fetal survival directly or by encouraging propagation of other inflammatory immune cells (Fig. 2).

\section{Uterine Tregs}

The kinetics of appearance of Tregs in the uterus suggests that these cells may be critical for successful implantation and maintenance of pregnancy. Using Treg depletion and transfer approaches in pregnant mice, several reports have confirmed a critical role of Tregs in implantation and pregnancy success. It has been reported that depletion of Tregs using different approaches prior to mating drastically impaired implantation (Aluvihare et al., 2004; Wang et al., 2014). Treg depletion before pairing led to massive effector $T$ cell infiltration and inflammation in the uterine microenvironment in both allogeneic and syngeneic mating pairs, suggesting that the presence of Tregs prior to implantation creates a pro-implantation microenvironment (Wang et al., 2014). On the other hand, Shima et al., have shown that post-implantation depletion of Tregs did not affect pregnancy outcome, implying that Tregs may not be needed for maintenance of pregnancy (Shima et al., 2010). However, these studies do not answer whether Tregs will become foes to pregnancy under adverse conditions, attack the fetus, and lead to pregnancy loss. Our unpublished observations support the view that uterine Tregs have the ability to become hostile to pregnancy when challenged in a poly I:C-induced microenvironment. These cells do not acquire Th17 phenotype yet induce fetal loss. This altered phenotype of uterine Tregs may be regulated by induced NF-kB transcriptional machinery.

\section{Clinical evidence}

\section{Uterine NK cells}

Recent literature is replete with emerging evidence for dysregulated NK cells and Tregs in recurrent spontaneous abortion (RSA), repeated implantation failure and other pregnancy complications (Quenby et al., 1999, 2009; Ntrivalas et al., 2001; Kwak-Kim et al., 2010). Three consecutive miscarriages define RSA and it affects $1-3 \%$ of all pregnancies. It is thought that unexplained RSA may involve the immune system. Although uNK cells are phenotypically and functionally distinct from their peripheral blood counterparts, controversial studies suggest that peripheral blood NK cells can be examined and used to discern uNK cell behavior in women with infertility and RSA. Most studies have focused on an increase in the content and cytotoxicity of peripheral blood NK cells. Since the percentage of NK cells varies in peripheral blood samples of healthy individuals, it is difficult to set a guideline percentage of these cells in women with RSA or infertility (Moffett et al., 2004). Moreover, since UNK cells are less cytotoxic compared to their circulating counterparts, measuring the cytotoxicity of peripheral blood NK cells may not provide relevant information on the characteristics of uNK cells (Moffett et al., 2004). Nevertheless, several recent studies have characterized uNK cells in RSA patients. It has been reported that the decidua from women with a history of RSA contains a very high number of granulysin-postive and CD56 bright $\mathrm{NK}$ cells (Nakashima et al., 2008). Interestingly, uNK cells have been shown to promote immune tolerance and successful pregnancy by dampening Th17 cells via IFN- $\gamma$ produced by the CD56 $6^{\text {bright }}$ CD27 ${ }^{+}$ subset (Fu et al., 2013). These observations suggest that this NK cell-mediated immune regulation is lost in RSA patients and is coupled with an elevated Th17 response and extensive local inflammation. We have previously demonstrated that decidual IL-10 deficiency in RSA patients was also associated with inflammatory responses (Plevyak et al., 2002). Since uNK cells and Tregs cells are potent producers of IL-10 in normal pregnancy and since this cytokine also dampens Th17 functions (Chaudhry et al., 2011; Stewart et al., 2013), it is plausible that extensive local inflammation is programmed by dysregulated uNK cells (Fig. 2).

\section{Uterine Tregs}

Recently, Tregs have also been extensively studied for their

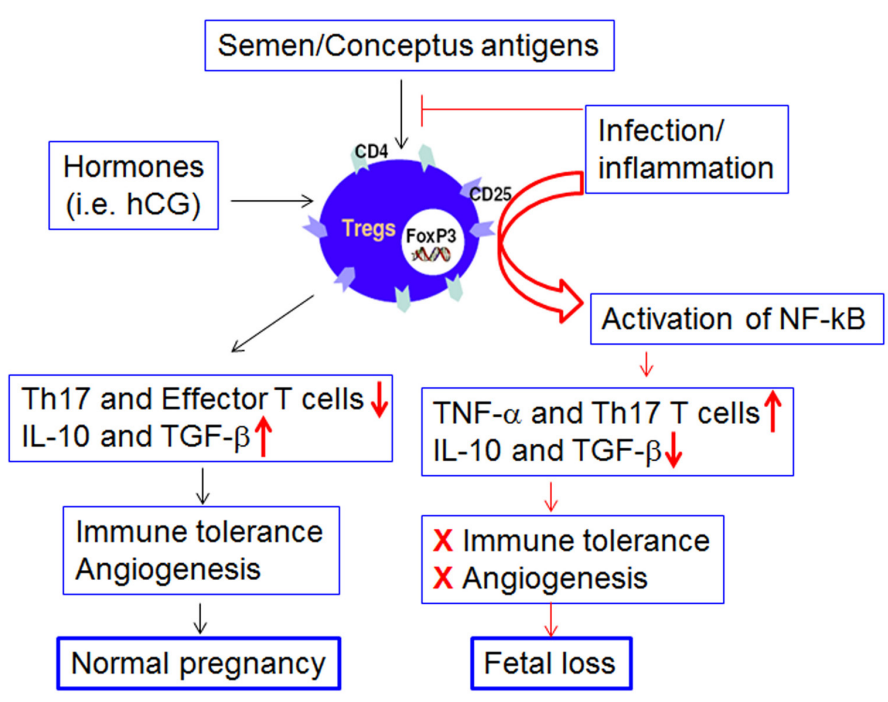

Fig. 3. Acquisition of inflammatory phenotype by uterine regulatory $\mathrm{T}$ cells (Tregs). As proposed in Figure 1, two sets of uterine Tregs could be generated during pregnancy. Semen/seminal fluid specific Tregs develop early and populate the implantation site. Their depletion or their poor development and recruitment may lead to implantation failure. Importantly, we propose that uterine Tregs could also be converted into inflammatoryTregs in response to bacterial and viral triggers. This could also lead to excessive production of TNF- $\alpha$ and presence of Th17T cells. This pathway will be the cause of break-down in immune tolerance and angiogenesis and eventually lead to fetal loss. Tregs are identified as cells intrinsically expressing surface $T$ cell markers CD4 and CD25 and the nuclear transcription factor FoxP3. 
altered phenotypic and functional characteristics in adverse pregnancy outcomes, particularly RSA (Sasaki et al., 2004; Lin et al., 2009; Nakashima et al., 2012; Othman et al., 2012; Inada et al., 2013, Quinn and Parast 2013). Again, the focus has been placed on the diagnostic use of peripheral blood Tregs. The use of circulating Tregs may or may not reflect the events at the maternal-fetal interface. Nevertheless, the question arises whether changes in Tregs seen in circulation are also seen at the maternal-fetal interface and whether the adverse uterine microenvironment dysregulate the local Treg population. There could be subtypes of Tregs in the decidua based on their phenotypic markers, but the important issue is whether these cells become detrimental to fetal growth. It is quite clear now that Tregs accumulate in response to specific antigens in different organs (Arpaia et al., 2013; Shafiai et al., 2013). For example, during homeostatic environment, commensal biota-specific Tregs accumulate in the gut-associated lymphoid system (Furusawa et al., 2013). Likewise, Tregs increase in number in the pregnant womb, possibly in response to fetal antigens (Rowe et al., 2012; Erlebacher 2013b). If they are to be altered in either percentage or function, the antigen cross-talk may be compromised. There is now evidence that Tregs can expand in response to microbial infections and can be deleted due to an adverse cytokine storm (Shafiai et al., 2013). This scenario may also exist in the uterus of RSA patients. Indeed, the Treg percentage has been shown to be decreased in the decidua of RSA patients (Sasaki et al., 2004; Liu et al., 2013; Quinn and Parast 2013). It has been shown that decreased Tregs are present in the decidua of miscarriage cases with normal fetal chromosome content. Decreased decidual Tregs may promote Th17 functions. Indeed, diminished Treg numbers in RSA patients have been shown to be accompanied with an increase in Th17 cells in circulation and decidua (Sasaki et al., 2004). Extrapolating from these studies, Winger and Reed have proposed that peripheral blood Tregs could be used as a superior marker for assessing miscarriage risk in newly pregnant women (Winger and Reed 2011). The caveat with all these studies is the substantial inter-individual variations and sample size of patients studied. Nevertheless, these results suggest that Tregs undergo changes in RSA or infertility which may be linked to hormonal dysregulation, impaired antigen education, or microbial infection and inflammation (Fig. 3). Experimental models can thus help in deciphering the exact roles of decidual Tregs in early pregnancy fetal loss.

\section{Conclusions and perspectives}

Currently, with the exception of anti-phospholipid antibody testing among women with RSA (Erkan et al., 2014), no other immunological test or immunomodulatory treatment exists that can be used for reproductive failures. Based on the preponderance of NK cells in the pregnant womb and experimental observations, it has been proposed that NK cells, including those from peripheral blood, could be used as a special predictive marker of RSA. However, this has been refuted because peripheral blood NK cells are distinct from those from decidual NK cells. The latter category is non-cytotoxic and provides angiogenic help by virtue of producing angiogenic factors. These cells also interact with invading trophoblast cells and direct them to transform spiral arteries in the uterus. We propose that the angiogenic properties of uNK cells impart a non-cytotoxic phenotype to these cells. It is perhaps an unscheduled break down of this phenotype that may be imprinted in the case of unexplained RSA. It may be possible to take advantage of peripheral blood NK cells to understand NK cell biology in RSA patients. Cerderia et al., have recently demonstrated that peripheral blood NK cells can be converted into a subpopulation which resembles decidual NK cells. It is possible that NK cells from RSA patients have lost this ability (Cerdeira et al., 2013). This difference can be exploited to understand the molecular defects in NK cells from RSA patients.

Similarly, uterine Tregs and even their peripheral blood counterparts may be superior markers in patients with RSA. One key feature of Tregs in pregnancy is that they increase in a pregnancydependent manner in both peripheral blood and uterine compartments. It has been shown that the percentage of Tregs decreases in RSA patients, suggesting that either Th17 cells take over or that fetal antigen dependent development of Tregs is impaired in response to inflammation, infection, or other environmental factors. A better understanding of these issues will advance the use of immunological marker in RSA patients. In this context, the observation that patients with a history of unexplained RSA experience reduced rate of miscarriage when treated with filgrastim (granulocyte colony stimulating factor) is noteworthy (Scarpellini and Sbracia 2009). It is also possible that uterine Tregs acquire an inflammatory phenotype and produce inflammatory cytokines instead of immunosuppressive IL-10 and TGF- $\beta$. These concepts should be pursued to better understand the causative mechanisms for early pregnancy loss. At least, this appears to be the case in experimental settings.

\section{Acknowledgements}

This work was supported in part by grants from NIH (P20RR018728) and NIEHS (P42ES013660). The author thanks James Padbury for critical reading and Megan Boudreau for help during preparation of the manuscript.

\section{References}

ALUVIHARE VR, KALLIKOURDIS M, and BETZAG (2004). Regulatory T cells mediate maternal tolerance to the fetus. Nat Immunol 5: 266-271.

ARNON TI, MARKEL G, and MANDELBOIM O (2006). Tumor and viral recognition by natural killer cells receptors. Sem Cancer Biol 16: 348-358.

ARPAIAN, CAMPBELL C, FAN X, DIKIY S, VAN DER VEEKEN J, DEROOS P, LIU H, CROSS JR, PFEFFER K, COFFER PJ, and RUDENSKY AY (2013). Metabolites produced by commensal bacteria promote peripheral regulatory $T$-cell generation. Nature 504: 451-455.

ASHKAR AA and CROY BA (1999). Interferon-gamma contributes to the normalcy of murine pregnancy. Biol Reprod 61: 493-502.

BALANDYA E, WIELAND-ALTER W, SANDERS K, and LAHEY T (2012). Human seminal plasma fosters CD4(+) regulatory $T$ cell phenotype and transforming growth factor $-\beta 1$ expression. Am J Reprod Immunol 68: 322-330.

BLOIS SM, KLAPP BF, and BARRIENTOS G (2011). Decidualization and angiogenesis in early pregnancy: unravelling the functions of DC and NK cells. J Reprod Immunol 88: 86-92

BARASH A, DEKEL N, FIELDUST S, SEGAL I, SCHECHTMAN E, and GRANOT I (2003). Local injury to the endometrium doubles the incidence of successful pregnancies in patients undergoing in vitro fertilization. Fertil Steril79: 1317-1322.

BIRON CA (2010). Expansion, maintenance, and memory in NK and T cells during viral infections: responding to pressures for defense and regulation. PLOS Pathog 6: e1000816.

BURTONGJ, YUNG HW, CINDROVA-DAVIEST, and CHARNOCK-JONESDS (2009) Placental endoplasmic reticulum stress and oxidative stress in the pathophysiology of unexplained intrauterine growth restriction and early onset preeclampsia. Placenta 30 (Suppl A): S43-S48.

CERDEIRA AS, RAJAKUMAR A, ROYLE CM, LO A, HUSAIN Z, THADHANI RI 
SUKHATME VP, KARUMANCHI SA, and KOPCOW HD (2013). Conversion of peripheral blood NK cells to a decidual NK-like phenotype by a cocktail of defined factors. J Immunol 190: 3939-3948.

CHAKRABORTY D, RUMI MA, and SOARES MJ (2012). NK cells, hypoxia and trophoblast cell differentiation. Cell Cycle 11: 2427-2430.

CHAKRABORTY D, RUMI MAK, KONNO T, and SOARES MJ (2011). Natural killer cells direct hemochorial placentation by regulating hypoxia-inducible factor dependent trophoblast lineage decisions. Proc Natl Acad Sci USA 108: 16295-16300.

CHAUDHRY A, SAMSTEIN RM, TREUTING P, LIANG Y, PILLS MC, HEINRICH JM, JACK RS, WUNDERLICH FT, BRUNING JC, MULLER W, and RUDENSKY AY (2011). Interleukin-10 signaling in regulatory $T$ cells is required for suppression of Th17 cell-mediated inflammation. Immunity 34: 566-578.

CO EC, GORMLEY M, KAPIDZIC M, ROSEN DB, SCOTT MA, STOLP HA, MCMASTER M, LANIER LL, BARCENA A, and FISHER SJ (2013). Maternal decidual macrophages inhibit NK cell killing of invasive cytotrophoblasts during human pregnancy. Biol Reprod 88:155.

CROY BA, CHEN Z, HOFMANN AP, LORD EM, SEDLACEK AL, and GERBER SA (2012). Imaging of vascular development in early mouse decidua and its association with leukocytes and trophoblasts. Biol Reprod 87: 125.

CROY BA, ESADEG S, CHANTAKRU S, VAN DEN HEUVEL M, PAFFARO VA, HE H, BLACK GP, ASHKAR AA, KISO Y, and ZHANG J (2003). Update on pathways regulating the activation of uterine natural killer cells, their interactions with decidual spiral arteries and homing of their precursors to the uterus. $J$ Reprod Immunol 59: 175-191.

CROY BA and KISO Y (1993). Granulated metrial gland cells: a natural killer cell subset of the pregnant murine uterus. Microsc Res Tech 25: 189-200.

CROY BA, ZHANG J, TAYADE C, COLUCCI F, YADI H, and YAMADA AT (2010). Analysis of uterine natural kiler cells in mice. Methods Mol Biol 612: 465-503.

DENG B, ZHU JM, WANG Y, LIU TT, DING YB, XIAO WM, LU GT, BO P, and SHEN $X Z$ (2013). Intratumor hypoxia promotes immune tolerance by inducing regulatory T cells via TGF- $\beta 1$ in gastric cancer. PLoS One 8: e637777.

DOSIOU C and GIUDICE LC (2005). Natural killer cells in pregnancy and recurrent pregnancy loss: endocrine and immunologic perspectives. Endocr Rev26: 44-62.

DRAKE PM and HEAD JR. (1989). Murine trophoblast can be killed by lymphokineactivated killer cells. J Immunol 193: 1199-1212.

ERKAN D, AGUIAR CL, ANDRADE D, COHEN H, CUADRADO MJ, DANOWSKI A, LEVY RA, ORTEL TL, RAHMAN A, SALMON JE, TEKTONIDOU MG, WILLIS $\mathrm{R}$, and LOCKSHIN MD (2014). 14 $4^{\text {th }}$ International congress on antiphospholipid antibodies task force report on antiphospholipid syndrome treatment trends. Autoimmun Rev 13: 685-696.

ERLEBACHER A (2013a). Immunology of the maternal-fetal interface. Annu Rev Immunol 31: 387-411.

ERLEBACHER A (2013b). Mechanisms of T cell tolerance towards the allogeneic fetus. Nat Rev Immunol 13: 23-33.

ERLEBACHER A, LAVIALLE C and GLIMCHER LH (2002). Intrinsic susceptibility of mouse trophoblasts to natural killer cells-mediated attack in vivo. Proc Natl Acad Sci USA 99: 16940-16945.

FACCIABENE A, PENG X, HAGEMANN IS, BALINT K, BARCHETTI A, WANG LP, GIMOTTY PA, GILKS CB, LAL P, ZHANG L, and COUKOS G (2011). Tumor hypoxia promotes tolerance and angiogenesis via CCL28 and $T(r e g)$ cells. Nature 475: 226-230.

FRIEDLINERH, BROWNDS, NGUYEN H, KORNFELD H, LEEJ, ZHANG Y, APPLEBY M, DERSD, KANG J, AND CHAMBERS CA (2009). CD4+regulatory T cells require CTLA-4 for the maintenance of systemic tolerance. J Exp Med 206: 421-434.

FU B, LI X, SUN R, TONG X, LING B, TIAN Z, WEI H (2013). Natural killer cells promote immune tolerance by regulating inflammatory $\mathrm{TH} 17$ cells at the human maternal-fetal interface. Proc Natl Acad Sci USA 110: E231-E240.

FURUSAWA Y, OBATA Y, FUKUDA S, ENDO TA, NAKATO G, TAKAHASHI D, NAKANISHI Y, UETAKE C, KATO K, KATO T, TAKAHASHI M, FUKUDA NN, MURAKAMI S, MIYAUCHI E, HINO S, ATARASHI K, ONAWA S, FUJIMURA Y, LOCKETTT, CLARKE JM, TOPPING DL, TOMITAM, HORIS, OHARAO, MORITA T, KOSEKI H, KIKUCHI J, HONDA K, HASE K, and OHNO H (2013). Commensal microbe-derived butyrate induces the differentiation of colonic regulatory $\mathrm{T}$ cells. Nature 504: 446-450.

GERSHON RK and KONDO K (1970). Cell interactions in the induction of tolerance: the role of thymic lymphocytes. Immunology 18: 723-737.
GNAINSKY Y, GRANOT I, ALDO PB, BARASH A, OR Y, SCHECHTMAN E, MOR $G$, and DEKEL N (2010). Local injury of the endometrium induces an inflammatory response that promotes successful implantation. Fertil Steril 94: 2030-2036.

GUERIN LR, MOLDENHAUER LM, PRINS JR, BROMFIELD JJ, HAYBALL JD, and ROBERTSON SA (2011). Seminal fluid regulates accumulation of FOXP3+ regulatory $T$ cells in the primplantation mouse uterus through expanding FOXP3+ cell pool and CCL19-mediated recruitment. Biol Reprod 85: 397-408.

HANNA J, GOLDMAN-WOHL D, HAMANI Y, AVRAHAM I, GREENFIELD C, NATANSON-YARON S, PRUS D, COHEN-DANIEL L, ARNON TI, MANASTER I, GAZIT R, YUTKIN V, BENHARROCH D, PORGADOR A, KESHET E, YAGEL $S$, and MANDELBOIM O (2006). Decidual NK cells regulate key developmental processes at the human fetal-maternal interface. Nat Med 12: 1065-1074.

HANNA J, WALD O, GOLDMAN-WOHL D, PRUS D, MARKEL G, GAZIT R, KATZ G, HAIMOV-KOCHMAN R, FUJII N, YAGEL S, PELED A, and MANDELBOIM O (2003). CXCL12 expression by invasive trophoblasts induces the specific migration of CD16- human natural killer cells. Blood 102: 1569-1577.

HARA M, KINGSLY CL, NIIMI M, READ S, TURVERY SE, BUSHELL AR, MORRIS PJ, POWRIE F, and WOOD KJ (2001). IL-10 is required for regulatory T cells to mediate tolerance to alloantigens in vivo. J Immunol 166: 3789-3796.

HEMBERGER M (2012). Immune balance at the foeto-maternal interface as the fulcrum of reproductive success. J Reprod Immunol 97: 36-42.

HIBY SE, APPS R, SHARSKEY AM, FARRELL LE, GARDNER L, MULDER A, CLASS FH, WALKER JJ, REDMAN CW, MORGAN L, TOWER C, REGAN L, MOORE GE, CARRINGTON M, and MOFFETT A. (2010). Maternal activating KIRs protect against human reproductive failure mediated by fetal HLA-C2. $J$ Clin Invest 120: 4102-4110.

HIBY SE, WALKER JJ, O'SHAUGHNESSY, REDMAN CW, CARRINGTON M, TROWSDALE J, and MOFFETT A (2004). Combinations of maternal KIR and fetal HLA-C genes influence the risk of preeclampsia and reproductive success. J Exp Med 200: 957-965.

HOFMANN AP, GERBER SA, and CROY BA (2014). Uterine natural killer cells pace early development of mouse decidua basalis. Mol Hum Reprod 20: 66-76.

HUGHES V (2014). Epigentics: The sins of the father. Nature 507: 22-24.

INADA K, SHIMA T, NAKASHIMA A, AOKI K, ITO M, and SAITO S (2013). Characterization of regulatory $T$ cells in decidua of miscarriage cases with abnormal or normal fetal chromosomal content. J Reprod Immunol 97: 104-111.

JABBOUR HN, SALES KJ, CATALANO RD, and NORMAN JE (2009). Inflammatory pathways in female reproductive health and disease. Reproduction 138: 903-919.

KALKUNTE S, CHICHESTER CO, GOTSCH F, SENTMAN CL, ROMERO R, and SHARMA S (2008). Evolution of non-cytotoxic uterine natural killer cells. Am J Reprod Immunol 59: 425-432.

KALKUNTE SS, MSELLE TF, NORRIS WE, WIRA CR, SENTMAN CL, SHARMA $S$ (2009). Vascular endothelial growth factor $C$ facilities immune tolerance and endovascular activity of human uterine NK cells at the maternal-fetal interface. $J$ Immunol 182: 4085-4092.

KING A and LOKE YW (1991). On the nature and function of human uterine granular lymphocytes. Immunol Today 12: 432-435.

KOPCOW HD, ALLAN DS, CHEN X, RYBALOV B, ANDZELM MM, GE B, and STROMINGER JL (2005). Human decidual NK cells form immature activating synapses and are not cytotoxic. Proc Natl Acad Sci USA 102: 15563-15568.

KUSUMI M, YAMASHITA T, FUJII T, NAGAMATSU T, KOZUMA S, and TAKETANI Y (2006). Expression pattern of lectin-like-natural killer receptors, inhibitoty CD94/ NKG2A, and activating CD94/NKG2C on decidual CD56bright natural killer cells differ from those on peripheral CD56dim natural killer cells. $J$ Reprod Immunol 70: 33-42.

LA CHAPELLE MH, MIRON P, HEMMINGS R, and ROY DC (1996). Endometrial T, $B$, and NK cells in patients with recurrent spontaneous abortion. Altered profile and pregnancy outcome. J Immunol 156: 4027-4034.

LASH GE, ROBSON SC, and BULMER JN (2010). Functional role of uterine natural killer (UNK) cells in human early pregnancy decidua. Placenta31(Suppl): S87-S92.

LE BOUTEILLER P and PICCINNI M-P (2008). Human NK Cells in pregnant uterus: why there? Am J Reprod Immunol 59:401-406

LE BOUTEILLER P and TABIASCO J (2006). Killers become builders during pregnancy. Nat Med 12: 991-992.

LIN Y, NAKASHIMA A, SHIMA T, ZHOU X, AND SAITO S (2009). Toll-like receptor signaling in uterine natural killer cells-role in embryonic loss. J Reprod Immunol 
83: 95-100

LIU C, WANG XZ, and SUN XB (2013). Assessment of sperm antigen specific T regulatory cells in women with recurrent miscarriage. Early Hum Dev 89: 95-100.

MANASTER I and MANDELBOIM O (2010). The unique properties of uterine NK cells. Am J Reprod Immunol 63: 434-444.

MEDAWAR PB (1953). Some immunological and endocrinological problems raised by evolution viviparity in vertebrates. Symp Soc Exp Biol 7: 320-328.

MOFFETT A and LOKE C (2006). Immunology of placentation in eutherian mammals. Nat Rev Immunol 6: 584-594.

MOFFETT A, REASAN L, and BRAUDE P (2004). Natural killer cells, miscarriage and infertility. Brit. J. Med. 329: 1283-1285

MOR G and CARDENAS I (2010). The immune system in pregnancy: a unique complexity. Am J Reprod Immunol 63: 425-433.

MUNOZ-SUANO A, HAMILTON AB, and BETZ AG (2011). Gimme Shelter: the immune system during pregnancy. Immunol Rev 241: 20-38.

MURPHY SP, FASTLD, HANNANN, and SHARMAS (2005). Uterine NK cells mediate inflammation-induced fetal demise in IL-10-null mice. J Immunol 175: 4084-4090.

MURPHY SP and SHARMA S (2004). IL-10 and pregnancy. In Immunology of Pregnancy, ed Gil Mor, Springer Science, NY, pp 26-36.

NAGLERA, LANIERLL, CWIRLAS, and PHILLIPS JH (1989). Comparative studies of human FcRIII-positive and negative natural killer cells. J Immunol 143:3183-3191.

NAKASHIMA A, SHIMA T, INADA K, ITO M, and SAITO S (2012). The balance of the immune system between T cells and NK cells in miscarriage. Am J Reprod Immunol 67: 304-310.

NAKASHIMAA, SHIOZAKIA, MYOJOS, ITOM, TATEMATSUM, SAKAIM, TAKAMORI Y, OGAWA K, NAGATA K, and SAITO S (2008). Granulysin produced by uterine natural killer cells induces apoptosis of extravillous trophoblasts in spontaneous abortion. Am J Pathol 173: 653-664.

NORRIS W, NEVERS T, SHARMA S and KALKUNTE S (2011). hCG, preeclampsia and regulatory T cells. Placenta 32 (Suppl 2): S182-S185.

NTRIVALAS EI, KWAK-KIM JY, GILMAN-SACHS A, CHUNG-BANG H, NG SC, BEAMAN KD, MANTOUVALOS HP, and BEER AE (2001). Status of peripheral blood natural killer cells in women with recurrent spontaneous abortions and infertility of unknown aetiology. Hum Reprod 16: 855-861.

OTHMAN R, OMAR MH, SHAN LP, SHAFIEE MN, JAMAL R, and MOKHTAR NM (2012). Microarray profiling of secretory-phase endometrium from patients with recurrent miscarriage. Reprod Biol 12: 183-199.

PAFFARO VA, BIZINOTTO MC, JOAZEIRO PP, and YAMADA AT (2003). Subset classification of mouse uterine natural killer cells by DBA lectin reactivity. Placenta 24: 479-488.

PEELS (1989). Granulated metrial gland cells. Adv Anat Embryol Cell Biol 115: 1-112.

PEEL S, STEWART I, and BULMER D (1979). Metrial gland cells in deciduomata of pseudopregnancy. J Anat 129: 21-30.

PIJNENBORG R, ROBERTSON WB, BROSENS I, and DIXON G (1981). Trophoblast invasion and the establishment of haemochorial placentation in man and laboratory animals. Placenta 2: 71-91.

PLEVYAK M, HANNA N, MAYER S, MURPHY S, PINAR H, FAST L, EKERFELT C, ERNERUDH J, BERG G, MATTHIESEN L, and SHARMA S (2002). Deficiency of decidual IL-10 in first trimester missed abortion: a lack of correlation with the decidual immune cell profile. Am J Reprod Immunol 47: 242-250.

QUENBY S, BATES M, DOIG T, BREWSTER J, LEWIS-JONES DI, JOHNSON PM, and VINCE G (1999). Pre-implantation endometrial leukocytes in women with recurrent miscarriage. Hum Reprod 14: 2386-2391.

QUENBY S, NIK H, INNES B, LASH G, TURNER M, DRURY J, and BULMER J (2009). Uterine natural killer cells and angiogenesis in recurrent reproductive failure. Hum Reprod 24: 45-54.

QUINN KH and PARAST MM (2013). Decidual regulatory T cells in placental pathology and pregnancy complications. Am J Reprod Immunol 69: 533-538.

RAI A and CROSS JC (2014). Development of the hemochorial maternal vascular spaces in the placenta through endothelial and vasculogenic mimicry. Dev Biol 387:131-141

RABINOVICH GA and TOSCANA MA (2009). Turning "sweet" on immunity: galectinglycan interactions in immune tolerance and inflammation. Nat Rev Immunol 9: 338-352.
RILEY JK and YOKOYAMA WM (2008). NK cell tolerance and the maternal-fetal interface. Am J Reprod Immunol 59: 371-387.

ROBERTSON SA, GUERIN LR, BROMFIELD JJ, BRANSON KM, AHLSTROM $A C$, and CARE AS (2009). Seminal fluid drives expansion of the CD4+CD25+T regulatory cell pool and induces tolerance to paternal alloantigens in mice. Biol Reprod 80: 1036-1045.

ROBERTSON SA, MAU VJ, TREMELLEN KP, and SEAMARK RF (1996). Role of high molecular weight seminal vesicle proteins in eliciting the uterine inflammatory response to semen in mice. J Reprod Fertil 107: 265-277.

ROBERTSON SA, PRINS JR, SHARKEY DJ, and MOLDERNHAUER LM (2013). Seminal fluid and the generation of regulatory $T$ cells for embryo implantation. Am J Reprod Immunol 69: 315-330.

ROBINS JC, MARSIT CJ, PADBURY JF, and SHARMA SS (2011). Endocrine disruptors, environmental oxygen, epigenetics and pregnancy. Front Biosci 3: 690-700.

ROWE JH, ERTELT JM, XIN L, and WAY SS (2012). Pregnancy imprints regulatory memory that sustains anergy to fetal antigen. Nature 490: 102-106.

SAITO S, SHIMA, T, INADA, K, and NAKASHIMAA (2013). Which types of regulatory $\mathrm{T}$ cells play important roles in implantation and pregnancy maintenance? $\mathrm{Am} \mathrm{J}$ Reprod Immunol 69: 340-345.

SAKAGUCHI S, SAKAGUCHI N, ASANO M, ITOH M, and TODA M (1995). Immunologic self-tolerance maintained by activated $T$ cells expressing IL-2 receptor alpha-chains (CD25). Breakdown of a single mechanism of self-tolerance causes various autoimmune diseases. J Immunol 155: 1151-1164.

SAKAGUCHI S, YAMAGUCHI T, NOMURA T and ONO M (2008). Regulatory T cells and immune tolerance. Cell 133: 775-787.

SAMSTEIN RM, JOSEFOWICZ SZ, ARVEY A, TREUTING PM, and RUDENSKY AY (2012). Extrathymic generation of regulatory $T$ cells in placental mammals mitigates maternal-fetal conflict. Cell 150: 29-38.

SASAKI Y, SAKAI M, MIYAZAKI S, HIGUMA S, SHOOZAKI A, and SAITO S (2004). Decidual and peripheral blood CD4+CD25+ regulatory $T$ cells in early pregnancy subjects and spontaneous abortion cases. Mol Hum Reprod 10: 347-353.

SCARPELLINI F and SBRACIAM (2009). Use of granulocyte colony-stimulating factor for the treatment of unexplained recurrent miscarriage: a randomised controlled trial. Hum Reprod 24: 2703-2708.

SCHOBER L, RADNAI D, SCHMITT E, MAHNKE KM SOHN C, and STEINBORN A (2012). Term and preterm labor: decreased suppressive activity and changes in composition of the regulatory T-cell pool. Immunol Cell Biol 90: 935-944.

SCHUBERT LA, JEFFREY E, ZHANG Y, RAMSDELL F, and ZIEGLER SF. (2001). Scurfin (FOXP3) acts as a repressor of transcription and regulates $T$ cell activation. J Biol Chem 276: 37672-37679.

SCHUMACHERA, HEINZE K, WITTE J, POLOSKI E, WOIDACKI K, and ZENCLUSSENAC (2013). Human chorionic gonadotropin as a central regulator of pregnancy immune tolerance. J Immunol 190: 2650-2658.

SCHUMACHER A and ZENCLUSSEN AC (2014). Regulatory T cells: regulators of life. Am J Reprod Immunol, in press. DOI: 10.1111/aji.12238.

SEOL H, OH M, LIM J, JUNG N, YOON S, and KIM H (2008). The role of CD+CD25 regulatory $\mathrm{T}$ cells in the maintenance of pregnancy, premature repture of membranes, and labor. Yonsei Med J 49: 366-371.

SHAFIANI S, DINH C, ERTELT JM, MOGUCHE AO, SIDDIQUI I, SMIGIEL KS, SHARMAP, CAMPBELLDJ, WAYSS, and URDAHLKB (2013). Pathogen-Specific Treg Cells Expand Early during Mycobacterium tuberculosis infection but are later eliminated in response to interleukin-12. Immunity 38:1261-1270.

SHIMA T, SASAKI Y, ITOH M, NAKASHIMA A, ISHII N, SUGAMURA K, and SAITO $S$ (2010). Regulatory T cells are necessary for implantation and maintenance of early pregnancy but not late pregnancy in allogeneic mice. J Reprod Immunol 85: $121-129$

SINGH M, CHAUDHRY P, and ASSELIN E (2011). Bridging endometrial receptivity and implantation: network of hormones, cytokines, and growth factors. $J$ Endocrinol 210: 5-14.

STEWART CA, METHENY H, IIDA N, SMITH L, HANSON M, STEINHAGEN F, LEIGHTY RM, ROERS A, CARP CP, MULLER W, and TRINCHIERI G (2013). Interferon-dependent IL-10 production by Tregs limits tumor Th17 inflammation $J$ Clin Invest 123: 4859-4874.

STEWART CL, KASPER P, BRUNET LJ, BHATT H, GADI L, KONGGEN F, and ABBONDANZO SJ (1992). Blastocyst implantation depends on maternal expression of leukemia inhibitory factor. Nature 359: 76-79. 
STEWART I (1988). Granulated metrial gland cells in the nontraumatized regions of the uterus of ovariectomized mice with deciduomata maintained on progesterone.J Endocrinol 116: 11-15.

TABIASCO J, RABOT M, AGUERRE-GIRRM, EL COSTAH, BERREBIA, PARANTO, LASKARIN G, JURETIC K, BENSUSSANA, RUKAVINAD, and LE BOUTEILLER $P$ (2006). Human decidual NK cells: unique phenotype and functional properties - a review. Placenta 27 (Suppl A): S34-S39.

TELES A, SCHUMACHER A, KUHNLE MC, LINZKE N, THUERE C, REICHARDT P, TADOKORO CE, HAMMERLING GJ, and ZENCLUSSEN AC (2013). Control of uterine microenvitonment by foxP3(+) cells facilitates embryo implantation. Front Immunol 4:158

THAXTON JE, NEVERS T, LIPPE EO, BLOIS SM, SAITO S, and SHARMA S (2013). NKG2D blockade inhibits poly(l:C)-triggered fetal loss in wild type but not in IL10\%- mice. J Immunol 190: 3639-3647.

THAXTON JE and SHARMA S (2010). Interleukin-10: a multi-faceted agent of pregnancy. Am J Reprod Immunol 63: 482-491.

TILBURGST, ROELEND, VANDERMASTB, DE GROOT-SWINGSGM, KLEIJBURG C, SCHERJON S, and CLAAS F (2008). Evidence for a selective migration of fetus-specific CD4+CD25 regulatory $T$ cells from the peripheral blood to the decudua in human pregnancy. J Immunol 180: 5737-5745.

TROEDSSON MH, LOSET K, ALGHAMDI AM, DAHMS B, and CRABO BG (2001). Interaction between equine semen and the endometrium: the inflammatory response to semen. Anim Reprod Sci 68: 273-278.

VACCAP, MINGARI MC, MORETTAL (2013). Natural killer cells in human pregnancy. $J$ Reprod Immunol 97: 14-19.

VAN DIJK M and OUDEJANS C (2013). (Epi)genetics of pregnancy-associated diseases. Front Genet 4: 180.
VASSILIADOU N and BULMER J (1998). Characterization of tubal and decidua leukocyte population in ectopic pregnancy: evidence that endometrial granulated lymphocytes are absent from tubal implantation site. Fertil Steril 69: 760-767.

VEIGA-PARGA T, SEHRAWAT S, and ROSE BT (2013). Role of regulatory T cells during virus infection. Immunol Rev 255: 182-196.

WANG WJ, LIU FJ, XIN-LIU, HAO CF, BAO HC, QU QL, and LIU XM (2014). Adoptive transfer of pregnancy-induced $C D+C D 25+$ regulatory $T$ cells reverses the increase in abortion rate caused by interleukin 17 in the CBA/JxBALB/c mouse model. Hum Reprod 29: 946-952.

WEISS G, GOLDSMITH LT, TAYLOR RN, BELLET D, and TAYLOR HS (2009). Inflammation in reproductive disorders. Reprod Sci 16: 216-229.

WINGER EE and REED JL (2011). Low circulating CD4(+)CD25(+) FoxP3(+) T regulatory cell levels predict miscarriage risk in newly pregnant women with a history of failure. Am J Reprod Immunol 66: 320-328.

XIONG H, ZHOU C, and QI G (2010). Proportional changes of CD4+CD25+ Fox P3 regulatory $T$ cells in maternal peripheral blood during pregnancy and labor at term and preterm. Clin Invest Med 33: E422.

YADIH, BURKE S, MADEJAZ, HEMBERGERM, MOFFETA, and COLUCCIF (2008). Unique receptor repertoire in mouse uterine NK cells. J.Immunol 181: 6140-6147.

ZHANG J, CHENZ, SMITH GN, and CROYBA(2011). Natural killer-triggered vascular transformation: maternal care before birth? Cell Mol Immunol 8: 1-11.

ZHENG LM, JOAG SV, PARR MB, PARR EL and YOUNG JD-E (1991). Perforinexpressing granulated metrial gland cells in murine deciduoma. J Exp Med 174: 1221-1226.

ZOU W (2006). Regulatory T cells, tumor immunity, and immunotherapy. Nat Rev Immunol 6: 295-307. 


\section{Further Related Reading, published previously in the Int. J. Dev. Biol.}

Immunoregulatory molecules in human placentas: potential for diverse roles in pregnancy Joan S. Hunt, Judith L. Pace and Ryan M. Gill

Int. J. Dev. Biol. (2010) 54: 457-467

http://dx.doi.org/10.1387/ijdb.082831jh

Split immunologiocal tolerance to trophobalst

Amanda De Mestre, Leela Noronha, Bettina Wagner and Douglas F. Antczak

Int. J. Dev. Biol. (2010) 54: 445-455

http://dx.doi.org/10.1387/ijdb.082795ad

The hidden maternal-fetal interface: events involving the lymphoid organs in maternalfetal tolerance

Elizabeth S. Taglauer, Kristina M. Adams Waldorf and Margaret G. Petroff

Int. J. Dev. Biol. (2010) 54: 421-430

http://dx.doi.org/10.1387/ijdb.082800et

Immune cells in the placental bed

Judith N. Bulmer, Paula J. Williams and Gendie E. Lash

Int. J. Dev. Biol. (2010) 54: 281-294

http://dx.doi.org/10.1387/ijdb.082763jb

A simple in vivo approach to investigate invasive trophoblast cells Juan A. Arroyo, Toshihiro Konno, Darya C. Khalili and Michael J. Soares

Int. J. Dev. Biol. (2005) 49: 977-980

http://dx.doi.org/10.1387/ijdb.051993ja

5 yr ISI Impact Factor $(2011)=2.959$

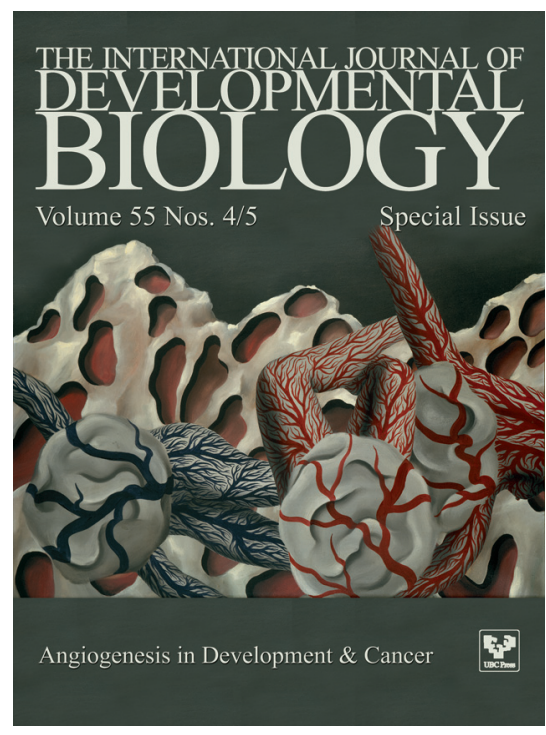

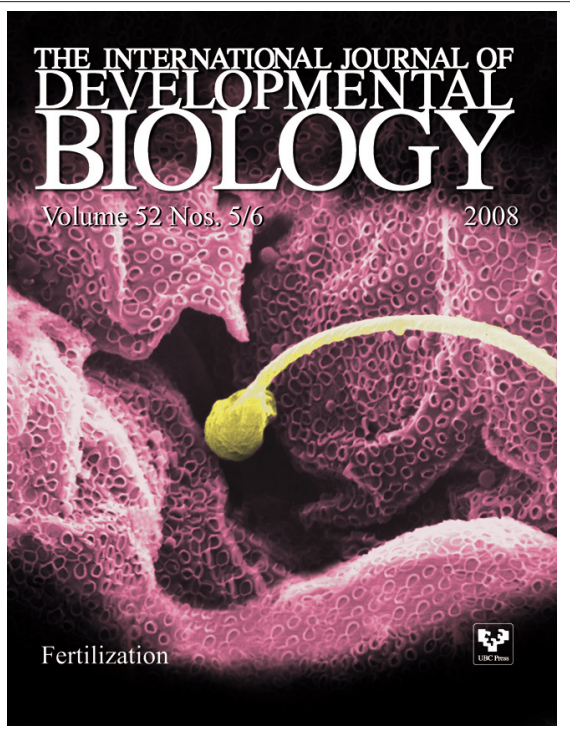
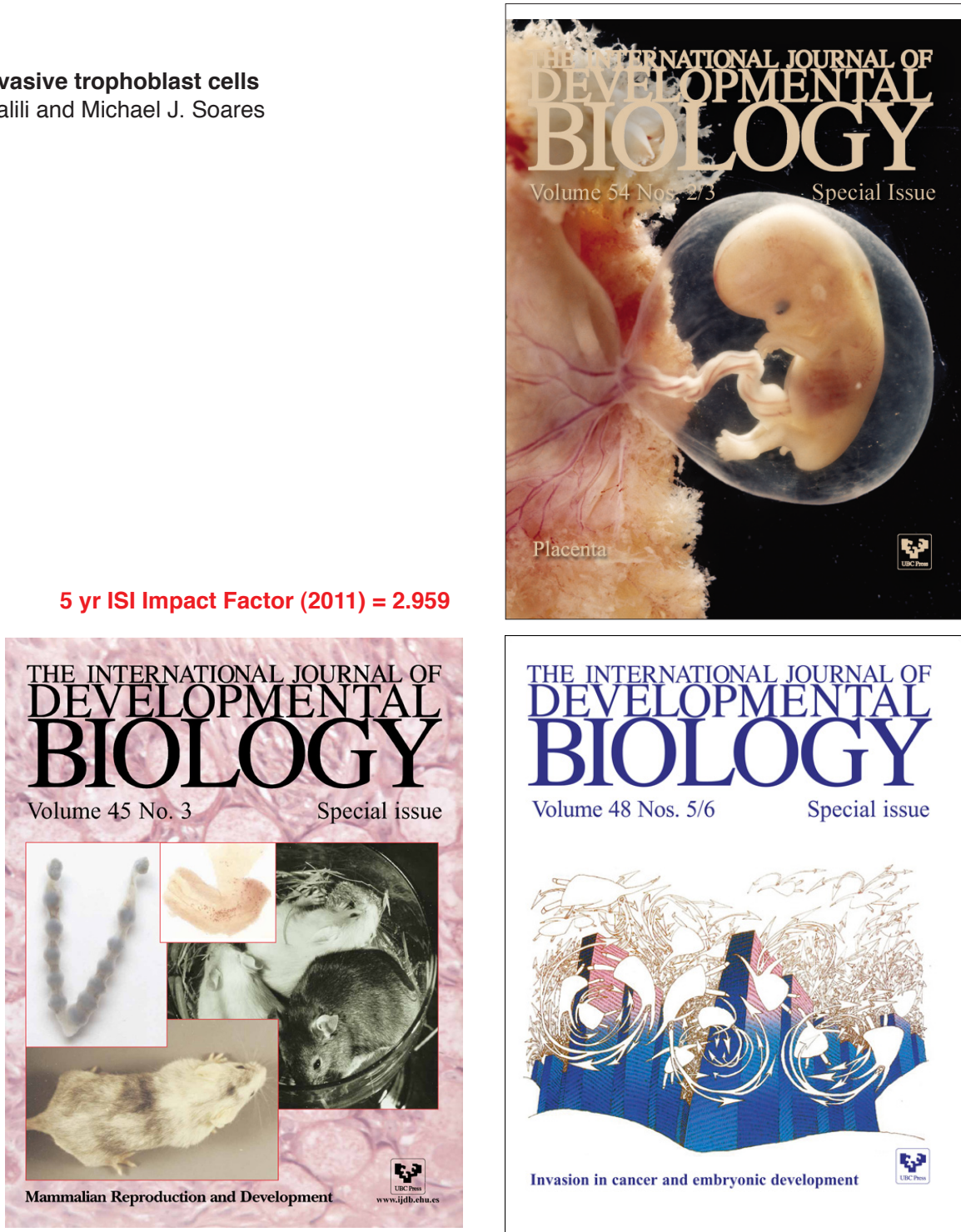

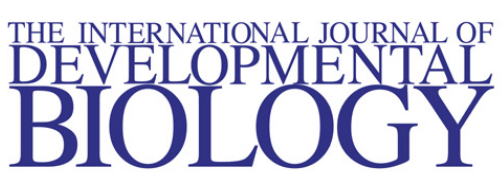

Volume 48 Nos. $5 / 6$

Special issue

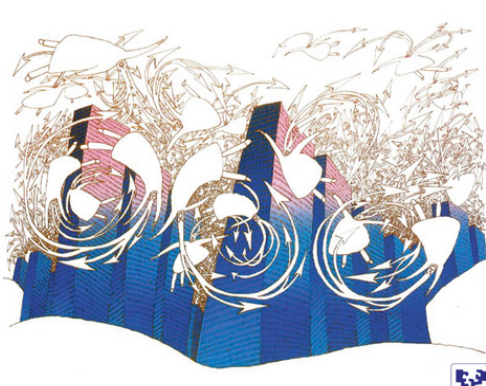

Invasion in cancer and embryonic development 